BEATA SKRZYDLEWSKA - LUBLIN

\title{
O POTRZEBIE BADAŃ NAD MUZEALNICTWEM KOŚCIELNYM
}

Zorganizowana z okazji ponad stulecia działalności muzeów kościelnych Konferencja, jest formą wyrażenia uznania dla trudu włożonego przez pionierów a także dla ich kontynuatorów w rozwój muzealnictwa kościelnego. Jest rodzajem akceptacji dla działalności związanej z ochroną zabytków podjętą przez Kościół katolicki.

Czas, który upłynął od założenia pierwszego polskiego muzeum kościelnego jest na tyle znaczący, że daje prawo do podsumowań, pozwala także na wychwycenie specyfiki tego rodzaju placówek.

Przyglądając się bliżej zagadnieniu muzealnictwa kościelnego, możemy stwierdzić, że w muzealnictwie kościelnym obecna jest cała, pełna kultura ludzka rozumiana w sensie klasycznym.

$\mathrm{W}$ tego typu muzeach, jak i w muzeach o innym profilu zauważalny jest zwłaszcza czynnik personalistyczny: poprzez uszanowanie tradycji człowiek traktowany jest podmiotowo. Równie ważny jest czynnik naukowy - opracowywanie zbiorów - ale szczególnie wyraźnie rysuje się sztuka, która obecna jest przynajmniej na dwa sposoby: muzea gromadzą dzieła sztuki, ale także zajmują się wystawiennictwem, zaś sama ekspozycja też może być dziełem sztuki.

W każdym muzeum, w tym także w muzeum kościelnym zabiega się o ukazanie integralnego obrazu, wymiaru eksponatu, poznajemy technikę wykonania dzieła, artystę, właściciela, kolekcja jest więc świadkiem tego kim jest człowiek.

Muzea Kościoła katolickiego mają charakter szczególny: jak w soczewce ogniskuje się w nich każdy aspekt kultury: ludzkie poznanie wraz z rozumieniem; ludzkie życie moralne wraz z obyczajowością; owoce twórczości artystycznej wraz z techniką i życie religijne osoby ludzkiej często ukazane na tle życia narodowego.

Zaskakuje fakt, że mimo ponad stuletniej działalności, pomimo tego, że muzealnictwo realizuje się w muzeach kościelnych w pełni, muzea te nie doczekały się kompleksowego opracowania. W związku z brakiem opracowań muzea kościelne są ośrodkami mało znanymi, a bardziej niż same muzea znane, są ich zbiory ${ }^{1}$.

${ }^{1}$ E. Ró ż á s k a, Muzea diecezjalne w Polsce, mps, Toruń 1976, s. 13. 
Głównym wątkiem mojego wystąpienia będzie zwrócenie uwagi na potrzebę rzetelnego przeprowadzenia badań nad muzealnictwem kościelnym.

Podczas przygotowywania w 2003 r. publikacji Muzea Kościoła katolickiego $w$ Polsce. Informator, starałam się zgromadzić najważniejszą literaturę dotyczącą poszczególnych muzeów a także ich zbiorów ${ }^{2}$. Analizując zebrany materiał, zaczęłam rozważać pomysł przygotowania pełnej bibliografii muzeów kościelnych. Podczas selekcjonowania materiału zauważyć się dało, że zagadnienia związane $\mathrm{z}$ muzealnictwem kościelnym rozpatrywane są $\mathrm{w}$ publikacjach $\mathrm{z}$ dziedziny historii, historii sztuki, muzealnictwa i w wydawnictwach popularyzatorskich.

Wśród opracowań, poruszających to zagadnienie, wyróżnić można kilka grup:

1. Wydawnictwa typu encyklopedycznego

2. Informatory

3. Monografie poszczególnych muzeów

4. Artykuły poświęcone wyłącznie zbiorom muzealnym, zarówno poszczególnym obiektom, jak też całym zespołom

5. Sprawozdania z działalności muzeów

6. Artykuły poświęcone ogólnym problemom muzealnictwa kościelnego: ochronie zabytków w terenie, dotyczące prawodawstwa muzealnego a także poświęcone działalności księży w dziedzinie ochrony dóbr kultury.

Muzea kościelne funkcjonują od I poł. XIX wieku, a jednak dotąd nie ma publikacji, która systematycznie i kompleksowo podejmowałaby się analizy historii i specyfiki muzeów kościelnych, co więcej, nie powstała żadna praca, która omawiałby choćby w jakimś wycinku chronologicznym wątek muzeów kościelnych. Powodów tego zaniedbania upatrywać należy w ideologizacji kultury, zwłaszcza w okresie komunizmu, kiedy to zaobserwować można było tendencję do deprecjonowania wkładu Kościoła katolickiego w kulturę a wiązało się to z narażeniem muzealnictwa na redukcjonizm (przykładem Muzea Ateizmu), a także, o czym mówię z przykrością z niedostateczną troska samych hierarchów Kościoła o tę dziedzinę kultury.

Pierwsze publikacje poświęcone ogólnej problematyce muzealnictwa kościelnego, zaczęły powstawać jeszcze na przełomie XIX i XX wieku. Kapłani na łamach różnych czasopism, zwłaszcza katolickich, pisali o potrzebie rozwoju badań nad ochroną zabytków, a także konieczności powoływania muzeów kościelnych, w których zabytki te znalazłyby nie tylko należyte schronienie, ale także troskliwą opiekę i mogłyby służyć badaniom naukowym.

Swego rodzaju cezurę czasową stanowi II Zjazd Historyków Polskich we Lwowie w 1890 r. ks. Edward Skrochowski, zaprezentował wówczas referat pt. O potrzebie zakładania muzeów dyecezyalnych dla zabytków artystycznego przemystu, archeologii i sztuki kościelnej $j^{3}$. Od tego czasu, do końca pierwszej wojny

\footnotetext{
${ }^{2}$ Muzea Kościoła katolickiego w Polsce. Informator, oprac. B. Skrzydlewska, Kielce 2004.

${ }^{3}$ E.Sk r o c h o w s k i, O potrzebie zakladania muzeów dyecezyalnych dla zabytków artystycznego przemystu, archeologii i sztuki kościelnej, w: Pamiętnik II Zjazdu Historyków Polskich we Lwowie, Lwów 1890.
} 
światowej, kiedy to z przyczyn oczywistych badania nad muzealnictwem kościelnym nie mogły rozwijać się należycie, w artykułach publikowanych w gazetach katolickich starano się szerzyć ideę muzealnictwa kościelnego ${ }^{4}$.

Po odzyskaniu przez Polskę niepodległości w artykułach skierowanych przede wszystkim do polskiego duchowieństwa, problematyka ochrony zabytków pojawia się na nowo. Na łamach gazet katolickich, zwłaszcza miesięczników wydawanych przez kurie diecezjalne, pojawiają się nazwiska księży, których możemy dzisiaj śmiało nazwać prekursorami polskiego muzealnictwa kościelnego. O swych spostrzeżeniach a często i postulatach dotyczących muzeów kościelnych pisali księża: S. Momidłowski w artykułach Cel zadania Muzeów Diecezjalnych, $W$ sprawie muzeum dyecezalnego, W. Górzański $O$ muzeach $w$ ogólności $i$ diecezjalnych $w$ szczególności; Cz. Chodorowski, O potrzebie utworzenia Muzeum Diecezjalnego; księża Bożek i Zdanowski we wspólnie napisanych artykułach $W$ sprawie muzeum diecezjalnego i $Z$ muzeum diecezjalnego ${ }^{5}$ W artykułach potrzebę powoływania muzeów diecezjalnych propagowali księża: J. Władziński Ochrona zabytków a nasze Muzeum Diecezjalne i A. Pleszczyński $W$ sprawie muzeum diecezjalnego ${ }^{6}$.

Tak jak przed laty pierwsza wojna światowa przerwała działalność muzealników kościelnych i rozwój badań nad tą dziedziną u samych podstaw jej rozwoju, tak wybuch drugiej wojny światowej zahamował rozważania naukowe na kolejnym etapie - w fazie działania ugruntowanych już muzeów.

Po drugiej wojnie światowej publikacje związane z ogólnymi zagadnieniami muzealnictwa, zaczęły ukazywać się dopiero pod koniec lat $50 \mathrm{XX}$ wieku. Wówczas powołano przy Katolickim Uniwersytecie Lubelskim, Ośrodek Archiwów, Bibliotek i Muzeów Kościelnych (1957 r.), którego głównym zadaniem było szerzenie wśród opiekunów zbiorów kościelnych wiedzy muzealnej, zarówno praktycznej jak i teoretycznej, poprzez wymianę doświadczeń, a także publikacje w wydawanym przez Ośrodek ABMK od 1959 r. czasopiśmie pod tytułem „Archi-

${ }^{4}$ Tenże, O potrzebie zakładania muzeów, dz.cyt.; J. R o k o s z ny, O potrzebie zaktadania muzeów dyecezyalnych dla zabytków sztuki kościelnej i archeologii, „Przegląd Katolicki” XL (1902) nr 9, s. 136-139; Te n ż e, Losy dziet sztuki i zabytków przeszłości w naszych kościołach, „Przegląd Katolicki” XLII (1904) nr 51, s. 806-807, nr 52, s. 821-823; S. M o m i d ł o w s k i, W sprawie muzeum dyecezalnego, „Kronika Diecezji Przemyskiej”, 5 (1905) z. 10., s. 307-310; T e n ż e, Muzeum diecezjalne dla sztuki kościelnej w Przemyślu, w: Rocznik Przemyski na rok 1909-1911, s. 67-76; Te n ż e, Cel i zadania muzeów diecezjalnych, „Pamiętnik Muzealny”, 2 (1933) s. 23-27; W. Gó r z y ń s k i, O muzeach w ogólności i dycezjalnych w szczególności, „Kronika Diecezji Kujawsko-Kaliskiej”, 3 (1909) nr 4, s. 110-111; Cz. Ch o d o r o w s k i, O potrzebie utworzenia muzeum Dycezyalnego, „Kielecki Przegląd Diecezjalny” 1 (1911) nr 1, s. 13-17.

${ }^{5} \mathrm{~A}$. B o że k, J. Z d a n ow s k i, W sprawie muzeum diecezjalnego, „Kielecki Przegląd Diecezjalny" 8 (1924) s. 178-179; J. Z d a n o w s k i, Seminarium duchowne w Kielcach. Szkic historyczny w dwóchsetna rocznicę zatożenia, Kielce 1927;

${ }^{6}$ J. W ła dzińs k i, Lubelskie Muzeum Diecezjalne, „Spójnia” 2 (1922) s. 1-3; Te n że, Ochrona zabytków a nasze Muzeum Diecezjalne, „Wiadomości Diecezjalne Lubelskie”, 3 (1925) s. 68-71; tamże, 4 (1925), s. 106-108; A. P le s z c zy ń s ki, W sprawie Muzeum diecezjalnego, „Spójnia”, 4-6 (1923) s. 3-5. 
wa, Biblioteki i Muzea Kościelne"7. Ukazanie się pierwszego numeru czasopisma poprzedził zjazd kierowników muzeów kościelnych, który odbył się w Lublinie w dniach 18-19 października $1957 \mathrm{r}$. Dał on początek cyklicznym sesjom naukowym $^{8}$. Organizatorzy Ośrodka zdawali sobie sprawę, że obowiązki osób zatrudnionych w muzeach kościelnych nie ograniczają się wyłącznie do spraw muzealnych, gdyż zakres działania kustoszy muzealnych znacznie wychodzi poza samo muzeum. Dlatego na organizowanych (i w latach późniejszych) sesjach poruszano kwestie związane z szeroko pojętą ochroną zabytków. Uznano za niezbędne publikowanie na łamach czasopisma artykułów ułatwiających rozwiązywanie problemów czysto praktycznych, a także zamieszczanie komunikatów lub sprawozdań z działalności muzeów 9 .

Postanowiono także zamieszczać wiadomości o aktualnych zbiorach kościelnych, ukazując ich współzależność z zasobami, jakie istniały w przeszłości na tle historii całych placówek ${ }^{10}$. Powyższe wiadomości miały przybliżać historię muzeów, nie mogły jednak być opracowaniami tak obszernymi, by uwzględniły odpowiednio szeroko zagadnienia związane z jedną placówką - nie mogły więc pretendować do rangi naukowo opracowanej monografii.

Przełomowym wydarzeniem w historii badań nad muzealnictwem kościelnym i ochroną sakralnych dóbr kultury, był rok 1962.Wtedy Episkopat Polski powołał do życia Komisję Episkopatu Polski do Spraw Sztuki Kościelnej, której zadaniem było organizowanie ogólnopolskich konferencji dla kierowników muzeów kościelnych ${ }^{11}$. Efektem prac Komisji są dwa dokumenty mające istotny wpływ na formowanie kościelnych placówek muzealnych. Są to: Normy postępowania

${ }^{7}$ B. S k rzy d l e w s k a, Historia i funkcjonowanie muzeów kościelnych, ABMK, 79 (2003) s. $183-188$.

${ }^{8}$ W. S mole ń, Stan i potrzeby muzeów kościelnych oraz program pracy na najbliższy rok, ABMK, 1 (1959) s. 43-56; Te n ż e, Projekt Statutu i Regulaminu muzeum diecezjalnego, ABMK, 2 (1961) s. 226-237.

${ }^{9}$ E. P r z e k o p, Kościelna ochrona zabytków i dóbr kultury wedtug Kodeksu Prawa Kanonicznego papieża Jana Pawła II, ABMK, 54 (1986) s. 31-40; S. G o m u ła, Zabezpieczenie obiektów sztuki wycofanych z użtku liturgicznego, tamże, s. 41-50; S. To m a s z k i e w i c z, Podstawowe wiadomości z konserwacji wymagane od kierownika muzeum kościelnego i rektora kościoła, tamże, s. 78-81; R. K n a p iń s k i, Dokumentacja w muzeach kościelnych, tamże, s. 82-99.

${ }^{10} \mathrm{~J}$. M y s z o r, Muzeum Diecezjalne w Katowicach, tamże, s.101-102; Z. K a p r o ń, Muzeum Diecezjalne Sztuki religijnej w Lublinie, tamże, s. 104-105; E. Ś 1 i w k a, Muzeum Misyjno - Etnograficzne Seminarium Duchownego Księży Werbistów w Pieniężnie, tamże, s. 106-109; R. K n a p i ń s k i, Muzeum Diecezjalne w Płocku, tamże, s. 110-118; S. To m a s z k i e w i c z, Muzeum Archidiecezjalne w Poznaniu, tamże, s.119-121; Z. B i e l a m o w i c z, Muzeum w Przemyślu, tamże, s. 122-124; J. Lewiński, Muzeum Diecezjalne sztuki kościelnej w Sandomierzu, tamże, s. 125-127; T. K u 1 i k, Muzeum Diecezjalne w Siedlcach, s. 128; H. J ę d r z e j e w s k i, Muzeum cystersów w Szczyrzycu, tamże, s. 129-131; W. S z c z e b a k, Muzeum Diecezjalne w Tarnowie, tamże, s. 132-139; K. B u r e k, Muzeum Archidiecezji Warszawskiej, tamże, s.140-145; J. P a t e r, Muzeum Archidiecezjalne we Wroclawiu, tamże, s.146-151.

${ }^{11}$ Dotychczas odbyły się trzy takie konferencje w 1978 i 1979 r. w Warszawie a w 1991 r. na Jasnej Górze w Częstochowie. 
w sprawach sztuki kościelnej, wydane 25 stycznia 1975 r. i Statut Muzeum Diecezjalnego zatwierdzony oficjalnie 18 listopada $1976 \mathrm{r}^{12}$.

Aktualnie prowadzone są badania indywidualne nad muzealnictwem kościelnym. Badacze skupiają się głównie przy Ośrodku ABMK, lub są jego stałymi współpracownikami. Dbałość o rozwój badań nad tą dziedziną jest szczególnie istotny, bowiem np. opracowań monograficznych dotyczących poszczególnych muzeów diecezjalnych, wziąwszy pod uwagę ich długoletnią historię, jest niewiele. Szczególne zdziwienie budzić może fakt, że spośród kilkunastu istniejących dzisiaj, tylko powstałe w 1888 r., Muzeum Diecezjalne w Tarnowie, doczekało się obszernej monografii. Autorem książki pod tytułem Muzeum Diecezjalne $w$ Tarnowie na tle dziejów muzealnictwa kościelnego w Polsce jest emerytowany już, wieloletni dyrektor tegoż muzeum ks. dr Władysław Szczebak ${ }^{13}$.

Przekrojowo historia muzeów, ich zbiory i działalność, często z uwzględnieniem danych bibliograficznych zawarta jest w pracach, w których omówione są wszystkie ważniejsze zbiory kolekcjonerskie w Polsce.

Pierwszą tego typu publikacją była książka Edwarda Chwalewika poświęcona polskim zbiorom bibliotecznym, archiwalnym i kolekcjom dzieł sztuki. Książka doczekała się dwóch wydań i w każdym z nich omówione były muzea diecezjalne. W wydaniu pierwszym uwzględnione są muzea w Kielcach, Krakowie, Lublinie, Płocku, Poznaniu, Przemyślu, Sandomierzu, Tarnowie, Włocławku i Żytomierzu, a w wydaniu drugim autor dołączył jeszcze muzea we Lwowie, Warszawie i Wrocławiu ${ }^{14}$.

W 1932 r. Mieczysław Orłowicz w książce Muzea i zbiory w Polsce, oprócz wielu muzeów polskich, podaje informacje, aczkolwiek bardzo skromne, o muzeach diecezjalnych w Krakowie, Poznaniu, Płocku i we Włocławku ${ }^{15}$.

Po drugiej wojnie światowej w książce Przewodnik po muzeach $i$ zbiorach w Polsce, Stanisław Lorentz, podaje bardzo krótkie wzmianki uwzględniające najważniejsze dane o muzeach w Kielcach, Pelplinie, Płocku, Poznaniu, Przemyślu, Sandomierzu, Tarnowie i Wrocławiu' ${ }^{16}$.

W 1997 r. Maria Sołtysiak i Katarzyna Wierzbicka, opracowały wydanie książkowe informatora Muzea w Polsce. Uwzględniły m.in. muzea diecezjalne

${ }^{12}$ Normy postępowania $w$ sprawach sztuki kościelnej wydane przez Konferencję Episkopatu Polski w Warszawie dnia 25 stycznia 1973 r., w: Dokumenty duszpastersko-liturgiczne Episkopatu Polski (1966-1993), oprac. Cz. Krakowiak, L. Adamowicz, Lublin 1994, s. 311-330; Statut Muzeum Diecezjalnego uchwalony przez Konferencję Episkopatu Polski dnia 18. XI. 1976 r., „Currenda", 127 (1977) nr 5-8, s. 169-170.

${ }^{13}$ W. S z c z e b a k, Muzeum Diecezjalne w Tarnowie na tle dziejów muzealnictwa kościelnego w Polsce, Tarnów 1994.

${ }^{14} \mathrm{E} . \mathrm{C} \mathrm{h} w \mathrm{a} 1 \mathrm{e} \mathrm{w} \mathrm{i}$ k, Zbiory polskie, archiwa, biblioteki, gabinety, galerie, muzea i inne zbiory pamiątek przeszłości $w$ ojczyźnie $i$ na obczyźnie $w$ porząlku alfabetycznym wedlug miejscowości ułożone, wyd. 1, Warszawa 1916, wyd. 2, Warszawa 1926-1927.

${ }^{15}$ M. O rło w i c z, Muzea i zbiory w Polsce, Warszawa 1932.

${ }^{16}$ S. L o r e n t z, Przewodnik po muzeach i zbiorach $w$ Polsce, wyd 1, Warszawa 1971, wyd. 2, Warszawa 1973. 
w Gnieźnie, Katowicach, Krakowie, Lublinie, Łodzi, Pelplinie, Płocku, Poznaniu, Przemyślu, Sandomierzu, Szczecinie, Warszawie i Wrocławiu, podając najważniejsze informacje, dotyczące godzin otwarcia i bardzo krótkiego zaprezentowania zbiorów ${ }^{17}$. Informatory poświęcone wyłącznie zbiorom kościelnym, wydawane były na łamach katolickich czasopism. Jako pierwszy informator tego typu opracował ks. Roman Nir ${ }^{18}$. Przedstawił dane odnoszące się do muzeów kościelnych, zarówno diecezjalnych, parafialnych jak i klasztornych. Omówił krótko historię placówek i zbiorów oraz dołączył przy niektórych placówkach krótkie dane bibliograficzne. Wśród muzeów diecezjalnych wymienił funkcjonujące wówczas muzea: w Gdańsku, Gnieźnie, Krakowie, Lublinie, Łodzi, Pelplinie, Płocku, Poznaniu, Przemyślu, Sandomierzu, Tarnowie, Warszawie, Włocławku, Wrocławiu, a także muzea w stadium organizacji: w Kielcach i Włocławku.

Na łamach pisma „Archiwa, Biblioteki i Muzea Kościelne” Maria Dębowska i Joachim Giela, opublikowali w 1993 r. Informator o muzeach kościelnych $w$ Polsce $^{19}$. Podobnie jak w publikacji ks. Romana Nira, uwzględnili nie tyko muzea diecezjalne (Częstochowa, Gniezno, Katowice, Kielce, Kraków, Płock, Poznań, Warszawa, Wrocław, Sandomierz, Tarnów), ale także parafialne i klasztorne. Muzea zostały omówione według następującego schematu: 1) adres, 2) personel, 3) historia, 4) charakterystyka zbiorów, 5) pomieszczenie, 6) ekspozycja, 7) inwentaryzacja, 8) księgozbiór, 9) publikacje o muzeum i zbiorach, 10) udostępnienie dla zwiedzających.

Najnowszy informator w formie samodzielnej publikacji książkowej, wydała Beata Skrzydlewska, w ramach cyklu „Biblioteka Ośrodka Archiwów Bibliotek i Muzeów Kościelnych Katolickiego Uniwersytetu Lubelskiego"20.

Informator sporządzany był na podstawie ankiet rozesłanych do poszczególnych muzeów kościelnych, w tym muzeów diecezjalnych. Muzea podane są w kolejności alfabetycznej miejscowości, oprócz danych najbardziej podstawowych jak znak, aktualny adres, numer telefonu, numer faksu, e-mail, strona www, nazwiska dyrektorów i innych pracowników, oraz czas udostępniania, podane zostały informacje dotyczące dziejów muzeum, charakterystyki eksponatów, księgozbioru i obszerna bibliografia dotycząca muzeum i jego zbiorów. Wśród muzeów diecezjalnych wymienianych w innych tego typu informatorach, jak muzea: w Częstochowie, Gnieźnie, Katowicach, Krakowie, Lublinie, Łodzi, Opolu, Pelplinie, Poznaniu, Przemyślu, Szczecinie, Sandomierzu, Tarnowie, Warszawie, we Wrocławiu, uwzględniono muzea nowo powstałe w Siedlcach (2000 r.), Rzeszowie (1998 r.), Zamościu (2000 r.).

Historia i działalność muzeów omawiana bywa często w książkach doty-

${ }^{17}$ M. S ołt y s i a k, K. W i e r z b i c k a, Muzea w Polsce. Informator, Warszawa 1997.

${ }^{18} \mathrm{R}$. N ir, Informator o archiwach, bibliotekach i muzeach kościelnych w Polsce, „Chrześcijanin w Świecie", 54 (1977) s. 191-206.

${ }^{19}$ M. D ę b o w s k a, J. G i e 1 a, Informator o muzeach kościelnych w Polsce, ABMK, 62 (1993) s. 313-378.

${ }^{20}$ Muzea Kościoła katolickiego w Polsce. Informator, oprac. B. Skrzydlewska, Kielce 2004. 
czących na przykład historii diecezji, lub miasta, w którym muzea się znajdują. W przypadku Muzeum Diecezjalnego w Płocku, którego historię i zbiory opisał ks. abp Antoni Julian Nowowiejski w księdze poświęconej historii Płocka ${ }^{21}$.

Najwięcej jest informacji okazjonalnych, zwykle o działalności muzeów, w szczególności na łamach gazet codziennych, one jednak nie mają rangi naukowej, choć oczywiście są cennym źródłem informacji dla badaczy.

Pewną nadzieję budzić może powstały w Instytucie Historii Sztuki nowy ośrodek badawczy: Katedra Muzealnictwa i Ochrony Zabytków, która miejmy nadzieję, podobnie jak dotychczas Ośrodek Archiwów Bibliotek i Muzeów Kościelnych zdoła skupić wokół siebie grono muzealników i stanie się miejscem rozwoju badań nad muzealnictwem kościelnym.

${ }^{21}$ A. N ow ow i e j s k i, Płock. Monografia. Monografia historyczna, wyd. 1, Płock 1917, wyd. 2, Płock 1930, s. 433-454. 